\title{
IN VITRO ANTIBACTERIAL ACTIVITIES OF ETHANOL EXTRACT OF IRANIAN PROPOLIS (EEIP) AGAINST FISH PATHOGENIC BACTERIA (AEROMONAS HYDROPHILA, YERSINIA RUCKERI \& STREPTOCOCCUS INIAE)
}

\author{
Amir Tukmechi ${ }^{1 *}$, Abdolghaffar Ownagh ${ }^{2}$, Ali Mohebbat ${ }^{2}$
}

\author{
${ }^{1}$ Department of Pathobiology \& Quality Control, Artemia \&Aquatic Animal Research Institute, Urmia University, Urmia, West \\ Azerbaijan, Iran; ${ }^{2}$ Department of Microbiology, Faculty of Veterinary Medicine, Urmia University, Urmia, West Azerbaijan, Iran.
}

Submitted: September 30, 2009; Approved: April 26, 2010.

\begin{abstract}
The "in vitro" antibacterial activity of ethanol extract of propolis (EEIP) from Urmia, Iran was investigated against three prevalent species of fish bacterial pathogens including: Aeromonas hydrophila LMG 3770, Yersinia ruckeri LMG 3279 and Streptococcus iniae LMG 14520. In this study two standard susceptibility testing techniques (Micro-broth dilution method and Agar-well diffusion method) were used to evaluation of the antibacterial activity of EEIP against the mentioned micro-organisms. Also the chemical composition of propolis was determined by the method of Gas chromatography-mass spectrometry (GC-MS). Twenty-six compounds were identified by gas chromatography-mass spectrometry analysis. Results showed Chemical composition of EEIP contained significant amounts of flavonoids, Sesquiterpenes - mainly Eudesmol and Caryophyllene oxide - aromatic acid, and low amounts of aldehydes and triterpens. Furthermore the ethanol extract of propolis inhibited the growth of all examined micro-organisms with the highest antimicrobial activity against Gram-positive bacteria Streptococcus iniae. Ethanol did not influence the antimicrobial effect of EEIP. These antibacterial properties would warrant further studies on the clinical applications of propolis in aquaculture field.
\end{abstract}

Key words: propolis, bee glue, antibacterial activity, chemical composition, fish pathogenic bacteria

\section{INTRODUCTION}

Fish are susceptible to several bacterial infections, mainly when reared in high densities conditions. Diseases outbreaks are responsible for elevated mortality rates and decrease of the productivity efficiency, causing high economic losses to the fish farmers (12). The use of antibiotics is the main treatment applied to control bacterial illness in fish farms. In order to the use of a wide variety of antibiotics, aquaculture has been implicated as potential environment to the development and selection of resistant bacteria and a source of these pathogens to other animals and humans $(6,12)$. For instance, the development of antibiotic resistance was reported in Aeromonas hydrophila, A. salmonicida, Edwardsiella tarda, E. icttaluri, Vibrio anguillarum, V. salmonicida, Pasteurella piscida and Yersinia ruckeri (25). The repetitive use of antibiotics in different fields (veterinary and human medicine) improves the emergence and occurrence of the resistance phenomenon in pathogenic bacteria. Some fish bacterial pathogens are also associated to diseases in humans (zoonotic or food borne diseases), making the aquaculture products as a potential risk to the customers (6). Regarding the problem of

*Corresponding Author. Mailing address: Department of Pathobiology and Quality Control, Artemia and Aquatic Animal Research Institute, Urmia University Shahid Beheshti Ave., Urmia, West Azerbaijan, Iran.; Tel.: +984413440295.; E-mail: atokmachi@gmail.com 
microbial resistance, there is an urgent need to establish the rules for the rational use of antibiotics and the discovery of new drugs and alternative therapies to control bacterial diseases in aquaculture field. Owing the ability to synthesize many different substances, the propolis is one of the top richest sources of new drugs $(1,11)$. It is showed that ethanol extract of propolis has a high potential as an alternative source of antibacterial compounds (2, 3, 4, 5, 13, 19, 20, 22, 33).

Propolis (bee glue) is a resinous hive product collected by honeybees (Apis mellifera carnica) from various plant sources and is used to seal holes in their honeycombs, smooth out the internal walls and protect the entrance against intruders (7). Propolis is a very complex mixture and, in general, it is composed of $50 \%$ balsams and resins, $30 \%$ wax, $10 \%$ essential oils, $5 \%$ pollen and $5 \%$ of various other substances like sugars, vitamins, etc $(16,30)$. Bees modify propolis by $\beta$-glucodiases, enzymes from hypopharyngeal glands, during collection and processing. Results of this enzymatic modification are hydrolyzation of phenolic compounds like flavonoid heterosides to free flavonoid aglycones and sugars and enhancement of the pharmacological action of the resulting products. Chemically, flavonoid aglycones from propolis are flavones, flavonols, flavanones, dihydroflavonols and chalcones. Other phenolic compounds are phenolic aldehydes and polyphenolic derivates of cinnamic and benzoic acid, including caffeic acid esters, terpenes, $\beta$-steroids, sesquiterpenes, naphthalene and stilbene derivatives (16).

Several investigations on propolis have been done in Eastern Europe and South America, but there is no report about antimicrobial effect of propolis in aquaculture previously. Therefore, the aim of the present study was to investigate the in vitro antimicrobial activity of ethanol extract of propolis from Iran against three fish pathogenic bacteria that are often the cause of bacterial diseases in aquaculture.

\section{MATERIALS AND METHODS}

\section{Propolis samples}

Crude propolis samples were collected from honey bee,
Apis mellifera carnica, colonies situated at the apiaries of Urmia, Iran. Hand collected propolis was kept in a dry place and stored at $4{ }^{\circ} \mathrm{C}$ until its processing. The sample was cut into small pieces and twenty five grams of ground propolis was extracted by $250 \mathrm{ml}$ of $80 \%$ ethanol by orbital shaking at 150 $\mathrm{rpm}$ at $25{ }^{\circ} \mathrm{C}$ for $48 \mathrm{hr}$. The ethanol extract was then filtered through a Whatman \#42 filter paper. Propolis samples were dried by evaporation, weighed and then diluted in ethanol to obtain a $10 \%(\mathrm{w} / \mathrm{v})$ solution. Samples were stored in the dark at $4{ }^{\circ} \mathrm{C}$ and used within 2 months of preparation $(3,33)$.

\section{Gas chromatography-mass spectrometry (GC-MS)}

A Finigan gas chromatography (Thermofinigan, USA) coupled with mass spectrometry (TRACE 2000 / EI quadrapole) was used for analysis of EEIP sample. It is equipped with a $30 \mathrm{~m} \times 0.25 \mathrm{~mm}$ ID, fused silica capillary column, which was chemically bonded with 0.25 m HP-5-MS stationary phase. The injector temperature was $260{ }^{\circ} \mathrm{C}$, the septum purge flow rate was $15 \mathrm{ml} / \mathrm{min}$, and the purge was turned on after $60 \mathrm{~s}$. The gas flow rate through the column was $1.5 \mathrm{ml} / \mathrm{min}$. The column initial temperature was kept at $100{ }^{\circ} \mathrm{C}$ for $5 \mathrm{~min}$. Finally temperature was increased from 100 to 280 ${ }^{\circ} \mathrm{C}$ at a rate of $20{ }^{\circ} \mathrm{C} / \mathrm{min}$, held on for $25 \mathrm{~min}$. Transfer line temperature was $250{ }^{\circ} \mathrm{C}$ and ion source temperature was 200 ${ }^{\circ} \mathrm{C}$. Helium was the carrier gas at $1 \mathrm{ml} / \mathrm{min}$; injection volume of $1 \mathrm{ml}$. Ionization was achieved by an $80 \mathrm{eV}$ electron beam at a current of $2.0 \mathrm{~mA}$. Masses were acquired in TIC when the acceleration voltage was turned on after a solvent delay of 100 s. All data were processed by Xcalibur (Thermofinigan, USA). Retention index for each peak/compounds was calculated by comparing its retention time against those of alkane series (C8C40, corresponding retention index values from 800 4000). All compounds were identified by comparing both the MS spectra and retention index with those available in libraries, i.e. NIST, Wiley, and internally compiled spectra libraries. For the quantification of the compounds in the ethanol extract, no any internal and external standard was used. Only percent reports, representing the percent concentration of each compound, obtained from peak area of target compound and total peak 
area of sum of peaks which exist in the same chromatogram were used. This was standard way to quantify the many similar organic compounds in the propolis samples. Measured percent concentration of each compound in propolis extracts, in this way, contains low relative error (not higher than 5\%) $(15,22)$.

\section{Bacterial strains}

The following micro-organisms were used in this study to test antimicrobial activity of propolis: Aeromonas hydrophila LMG 3770, Yersinia ruckeri LMG 3279 and Streptococcus iniae LMG 14520. All micro-organisms were provided by Belgian Co-ordinated Collections of Micro-organism, Belgium. All bacteria were cultured for $18 \mathrm{~h}$ at $28{ }^{\circ} \mathrm{C}$ in brain heart infusion broth (Merck, Darmstadt, Germany) and used as inoculums.

\section{Susceptibility tests}

The following methods were used to evaluate the activity of the EEIP. All tests were repeated three times, using an $80 \%$ ethanol solution without propolis as a control to test the inhibitory effect of the solvent.

\section{Micro-broth dilution method}

Minimum inhibition concentrations (MIC) of EEIP against the tested pathological bacterial strains were determined using micro-broth dilution method (26). Briefly, serial two-fold dilutions of EEIP $(10 \% \mathrm{w} / \mathrm{v})$ were prepared in 96-well microtiter plate ((from 1: 2 to 1: 8192) containing cation-adjusted Mueller-Hinton broth (Merck, Darmstadt, Germany). Control micro-titer plates containing medium and $80 \%$ ethanol at the same dilutions were also made. Bacterial suspensions were adjusted to the $0.5 \mathrm{McFarland}$ standards (approximately 1 to 2 $\times 10^{8} \mathrm{CFU} / \mathrm{ml}$ ). A constant amount of bacteria were added to all wells and the plate was incubated at $28^{\circ} \mathrm{C}$ for $18-24$ hour (final inoculate were adjusted to the $10^{5} \mathrm{CFU}$ per each well). Each well was examined for growth, comparing each well to the control. The MIC was defined as the lowest concentration of propolis at which there was no visible growth of the organisms. For each test enrofloxacin and gentamycin were used as the control antimicrobial agents. The minimal bactericidal concentration $(\mathrm{MBC}$; the lowest concentration of propolis that resulted in a $99.9 \%$ reduction in CFU of the initial inoculums) was determined by plating count the contents of wells that showed no visible growth of bacteria onto MuellerHinton agar (Merck, Darmstadt, Germany) plates and incubating at $28^{\circ} \mathrm{C}$ for $18 \mathrm{~h}$. The $\mathrm{MBC}$ was considered the lowest concentration of propolis that prevented any colony formation.

\section{Agar-well diffusion method}

Antibacterial activities of EEIP were tested by agar-well diffusion method. Besides, the antimicrobial activity of EEIP was compared with antibiotics (enrofloxacin and gentamycin). Petri dishes with $10 \mathrm{ml}$ of Mueller-Hinton agar were prepared, previously inoculated with $0.1 \mathrm{ml}$ of a $24 \mathrm{~h}$ broth culture of test bacteria. Three wells $(6 \mathrm{~mm})$ were made and filled with $50 \mu \mathrm{l}$ of the ethanol extract. The inoculated plates were incubated for $24 \mathrm{~h}$ at $28^{\circ} \mathrm{C}$. After incubation, the diameter of the inhibition zone was measured with calipers (14).

\section{Statistical Analysis}

All the statistical analyses were performed by the SPSS 11.0 (SPSSFW, SPSS Inc., Chicago, USA) statistical package.

\section{RESULTS}

In vitro, screening antibacterial activity of ethanol extract of propolis against fish bacterial pathogens was subjected to biological testing. To substantiate the antibacterial results, we screened EEIP against an assortment of two Gram negative bacteria (Aeromonas hydrophila, Yersinia ruckeri) and one Gram positive bacteria (Streptococcus iniae) using enrofloxacin and gentamycin as a reference standard. The bacteriostatic (MIC) and bactericidal (MBC) activity of ethanol extract of propolis against these pathogenic bacteria are shown in Table 1. Growth inhibition was observed in A. hydrophila, $Y$. ruckeri and $S$. iniae by the solutions containing 781.25, 390.62 and $195.3 \mu \mathrm{g} / \mathrm{ml}$ of propolis, corresponding to a 1: $128,1: 256$ 
and 1: 512 dilution of the $10 \%$ ethanol extract, respectively. Control studies showed that the residual amount of ethanol in the extract inhibited A. hydrophila, $Y$. ruckeri growth only to a 1: 4 and 1: 3 dilutions, respectively; but ethanol did not any effect on the growth of $S$. iniae.

The mean diameters of microbial growth inhibited by different concentrations of EEIP are shown in Table 2. Using the Agar-well diffusion technique, a linear regression curve (not reported) was obtained, but 781.25, 390.62 and 195.3 $\mu \mathrm{g} / \mathrm{ml}$ were the minimal concentrations of propolis that permitted measurement of the diameter of the zone of inhibition for A. hydrophila, $Y$. ruckeri and $S$. iniae, respectively. As well as assays carried out with disks inoculated with the different concentrations of EEIP revealed an irregular diffusion of the substance and are not suitable for comparing specimens.

Chemical composition of $80 \%$ ethanol extract of propolis sample from Urmia was assessed by GC/MS analysis. The identified compounds have listed in Table 3. The main flavonoid compounds in derivatized ethanol extract of propolis were Pinostrobin, Dihydrochrysin, Chrysin and Naringenin.

Table 1. Minimum inhibition concentration (MIC) and minimum bactericidal concentration (MBC) of propolis against $A$. hydrophila, Y. ruckeri and S. iniae.

\begin{tabular}{|c|c|c|c|c|c|c|}
\hline \multirow[b]{2}{*}{ Agent } & \multicolumn{2}{|c|}{ A. hydrophila } & \multicolumn{2}{|c|}{ Y. ruckeri } & \multicolumn{2}{|c|}{ S. iniae } \\
\hline & $\mathrm{MIC}(\mu \mathrm{g} / \mathrm{ml})$ & $\mathrm{MBC}(\mu \mathrm{g} / \mathrm{ml})$ & $\mathrm{MIC}(\mu \mathrm{g} / \mathrm{ml})$ & $\mathrm{MBC}(\mu \mathrm{g} / \mathrm{ml})$ & $\mathrm{MIC}(\mu \mathrm{g} / \mathrm{ml})$ & $\mathrm{MBC}(\mu \mathrm{g} / \mathrm{ml})$ \\
\hline propolis & 781.25 & 1562.5 & 390.62 & 1562.5 & 195.31 & 195.31 \\
\hline Enrofloxacin & 31.25 & $62.5-125$ & 62.5 & 125 & 15.625 & $31.25-62.5$ \\
\hline Gentamycin & 312.5 & 625 & 1250 & 1250 & 2500 & 5000 \\
\hline
\end{tabular}

Table 2. The mean of the Diameters of inhibition zone ${ }^{1}(\mathrm{~mm})$ of bacterial growth inhibited by different concentrations of ethanol extract of propolis and standard antibiotics.

Bacteria

EEIP $^{2}$ concentrations $\quad$ Enrofloxacin Gentamycin

\begin{tabular}{llllllllllllllcc} 
& \cline { 2 - 3 } & 1 & 2 & 3 & 4 & 5 & 6 & 7 & 8 & 9 & 10 & 11 & 12 & $5 \mu \mathrm{g} / \mathrm{disk}$ & $10 \mu \mathrm{g} / \mathrm{disk}$ \\
A. hydrophila & 17.5 & 14 & 12 & 11 & 10.5 & 9 & 8 & - & - & - & - & - & 32 & 24 \\
Y. ruckeri & 18 & 15 & 14.5 & 12 & 11 & 9 & 7.5 & 7 & - & - & - & - & 33 & 23 \\
S. iniae & 21 & 19 & 19 & 15 & 13 & 12.5 & 11 & 11.5 & 9 & - & - & - & 33 & 22
\end{tabular}

\footnotetext{
${ }^{\mathrm{T}}$ Values expressed are averages of three replicates.

${ }^{2} 1=50,000 \mu \mathrm{g} / \mathrm{ml}, 2=25,000 \mu \mathrm{g} / \mathrm{ml}, 3=12,500 \mu \mathrm{g} / \mathrm{ml}, 4=6,250 \mu \mathrm{g} / \mathrm{ml}, 5=3,125 \mu \mathrm{g} / \mathrm{ml}, 6=1562.5 \mu \mathrm{g} / \mathrm{ml}, \quad 7=781.25 \mu \mathrm{g} / \mathrm{ml}, 8=390.62 \mu \mathrm{g} / \mathrm{ml}, 9=$ $195.31 \mu \mathrm{g} / \mathrm{ml}, 10=97.65 \mu \mathrm{g} / \mathrm{ml}, 11=48.82 \mu \mathrm{g} / \mathrm{ml}$ and $12=24.41 \mu \mathrm{g} / \mathrm{ml}$.
} 
Table 3. Chemical composition of ethanol extract of propolis.

\begin{tabular}{|c|c|c|}
\hline Compounds & Percent composition & Retention Time \\
\hline \multicolumn{3}{|l|}{ Aldehydes } \\
\hline 2-Hydroxy-5-methylbenzaldehyde & 2.22 & 9.77 \\
\hline \multicolumn{3}{|l|}{ Flavonoids } \\
\hline 5-Hydroxy-7-methoxy flavanone (pinostrobin) & 8 & 15.14 \\
\hline 5,7,40-Trihydroxy flavanone (naringenin) & 3.14 & 15.53 \\
\hline 5,7-Dihydroxy flavone (chrysin) & 5.41 & 16.08 \\
\hline Dihydrochrysin & 9.69 & 14.37 \\
\hline \multicolumn{3}{|l|}{ Aromatic acids } \\
\hline 3(3,4-Dihydroxyphenyl)-2-propenoic acid (caffeic acid) & 5.09 & 13.51 \\
\hline \multicolumn{3}{|l|}{ Sesquiterpenes } \\
\hline Cis-lanceol & 2.22 & 10.15 \\
\hline Caryophyllene oxide & 7.38 & 11.48 \\
\hline Eudesmol & 7.38 & 10.57 \\
\hline 6-Hydroxy-1-oxogermacr-4,10(15),11(13)-trien-12,8-olide & 0.2 & 12.33 \\
\hline \multicolumn{3}{|l|}{ Triterpenes } \\
\hline 3,12-Oleandione & 0.52 & 17.77 \\
\hline \multicolumn{3}{|l|}{ Alcohol } \\
\hline 1-Heptatriacotanol & 2.16 & 12.25 \\
\hline \multicolumn{3}{|l|}{ Aliphatic hydrocarbons } \\
\hline 1,5,5-Trimethyl-6-methylene-cyclohexene & 3.01 & 13.02 \\
\hline Alfaxalone & 5.09 & 13.89 \\
\hline \multicolumn{3}{|l|}{ Aromatic hydrocarbons } \\
\hline 2-Amino-1-(3-hydroxy-4-methoxyphenyl) ethanone & 5.87 & 13.31 \\
\hline 1,3,8-trihydroxy-6-methylanthracene-9,10-dione & 4.27 & 16.54 \\
\hline
\end{tabular}

${ }^{a}$ Percent composition of the compounds was calculated from the total ion chromatogram of the percent peak are of each component without any correction.

\section{DISCUSSION AND CONCLUSION}

The ethanol extract of propolis exhibited an inhibition in the growth of all examined pathogenic bacteria including: $A$. hydrophila, Y. ruckeri and S. iniae; showing the highest antibacterial activity against Gram positive bacterium with the MIC of $195.3 \mu \mathrm{g} / \mathrm{ml}$. The antibacterial activity probably attributed to the presence of high levels of flavonoids, sesquiterpenes and caffeate esters compounds (table 3). The results of the antimicrobial activity of ethanol extract of propolis is in agreement with the findings of Bosio et al. (2000); Kilic et al. (2005); Ferreira et al., (2007);
Mohammadzadeh et al. (2007) and Kalogeropoulos et al. (2009), who found that the antimicrobial activity of propolis can be attributed to its components as pinostrobin, naringenin, chrysin, dihydrochrysin and caffeic acid esters.

Saroglou et al. (2005) proposed that the antimicrobial action of propolis is complicated and could be due to the synergism between flavonoids, hydroxyl acids, and sesquiterpenes. It was experimentally demonstrated that not even a single component isolated from propolis showed an activity higher than the total extract $(18,21,24,28)$. The synergistic effect between the different components of propolis was already reported by Scheller et al. and latter confirmed by 
Krol et al., (1993).

The Gram positive bacterium tested was highly sensitive already to lower concentrations of propolis, but the Gram negative bacteria A. hydrophila and Y. ruckeri displayed a lower sensitivity to the EEIP than $S$. iniae. The results of this study are in agreement with findings by several researchers, who reported the Gram negative bacteria have lower sensitivity to propolis than Gram positive bacteria $(1,8,19,23,31)$. The most plausible explanation for the less sensitivity of Gram negative bacteria is their outer membrane that inhibits and/or retards the penetration of propolis at lower concentrations. Another possible reason why the Gram negative bacteria are more resistant to propolis might be the possession of multidrug resistance pumps (MDRs), which extrude amphipathic toxins across the outer membrane $(10,30)$. The presence of MDRs in E. coli and their role in the insensitivity of the bacterium to antimicrobials was clearly elucidated (32).

The relatively lower sensitivity of Gram negative bacteria compared to the more sensitive Gram positive ones, at least at lower concentrations, could be traced to an activity that involves the Gram positive bacterial cell wall, inhibition of cell wall synthesis and hence distortion of its integrity. Electron microscopic pictures displayed that propolis treated cells possessed defective cell walls and failed to separate after cell division and formed a pseudo-multicellular structure. An experiment with a known antibiotic demonstrated that the formation of a pseudo-multicellular structure after treatment could be due to the blockage of the so-called splitting system of the cross wall (31).

Based on the data obtained from the present study, it is concluded that ethanol extract of propolis exhibited significant antibacterial activity against fish pathogenic bacteria. Hitherto investigations of propolis did not point out one individual substance or a particular substance class which could be entirely responsible for this action. Obviously a synergistic action is essential in all samples for the biological activity of bee glue. It seems that the chemical nature of propolis is beneficial not only to bees but have general pharmacological values as an antimicrobial natural product.
At the best of our knowledge, this study is the first report of antibacterial activity of ethanol extract of Iranian propolis against fish pathogenic bacteria. These antibacterial properties would warrant further studies on the clinical applications of propolis in aquaculture field.

\section{ACKNOWLEDGEMENT}

This work was supported by Artemia and Aquatic Animal Research Institute and faculty of veterinary medicine, Urmia University. Also, we would like to thank the Dr. Farshad Kheiri for chemical analyzing of the ethanol extract of propolis by the method of GC-MS.

\section{REFERENCES}

1. Banskota, A.H.; Tezuka, Y.; Kadota, S. (2001). Recent Progress in Pharmacological Research of Propolis. Phytother. Res. 15, 561-571.

2. Basim, E.; Basim, H.; Ozcan, M. (2006). Antibacterial activities of Turkish pollen and propolis extracts against plant bacterial pathogens. $J$. Food Process. Eng. 77, 992-996.

3. Bosio, K.; Avanzini, C.; Avolio, A.D.; Ozino, O.; Savoia, D. (2000). In vitro activity of propolis against Streptococcus pyogenes. Lett. Appl. Microbiol. 31, 174-177.

4. Burdock, G.A. (1998). Review of the Biological Properties and Toxicity of Bee Propolis (Propolis). Food Chem. Toxicol. 36, 347-363.

5. Castro, M.L.; Vilela, W.R.; Zauli, R.C.; Ikegaki, M.; Rehder, V.L.G.; Foglio, M.A.; Alencar, S.M.; Rosalen, P.L. (2009). Bioassay guided purification of the antimicrobial fraction of a Brazilian propolis from Bahia state. BMC Complemen. Altern. Med. 9, 25-30.

6. Castro, S.B.R.; Leal, C.A.G.; Freire, F.R.; Carvalho, D.A.; Oliveira, D.F.; Figueiredo, H.C.P. (2008). Antibacterial activity of plant extracts from Brazil against fish pathogenic bacteria. Braz. J. Microbiol, 39, 756-760.

7. El-Bassuony, A.A. (2009). New prenilated compound from Egyptain propolis with antibacterial avtivity. Rev. Latinoamer. Quím. 37 (1), 85 90.

8. Farnesi, A.P.; Aquino-Ferreira, R.; Jong, D.D.; Bastos, J.K.; Soares, A.E.E. (2009). Effects of stingless bee and honey bee propolis on four species of bacteria. Genet. Mol. Res. 8 (2), 635-640.

9. Ferreira, F.B.A.; Torres, S.A.; Marcucci, M.C. (2007). Antimicrobial effect of propolis and other substances against selected endodontic pathogens. Oral. Surg. Oral. Med. Oral. Pathol. Oral. Radiol. Endod. 104, 709-716.

Garedewa, A.; Schmolza, E.; Lamprecht, I. (2004). Microbiological and calorimetric investigations on the antimicrobial actions of different 
10. propolis extracts: an in vitro approach. Thermochim. Act, 422, 115-124.

11. Grange, J.M.; Davey, R.W. (1990). Antibacterial properties of propolis (bee glue). J. R. Soc. Med., 83 (3), 159-160.

12. Hatha, M.; Vivekanandhan, A.A.; Joice, G.J.; Christol (2005). Antibiotic resistance pattern of motile aeromonads from farm raised fresh water fish. Int. J. Food Microbiol. 98, 131-134.

13. Kalogeropoulos, N.; Konteles, S.J.; Troullidou, E.; Mourtzinos, I.; Karathanos, V.T. (2009). Chemical composition, antioxidant activity and antimicrobial properties of propolis extracts from Greece and Cyprus. $J$. Food Chem. 116, 452-461.

14. Katiroglu, H.; Beyatli, Y.; Aslim, B.; Yüksekdag, Z.; Atici, T. (2006). Screening for Antimicrobial Agent Production of Some Microalgae in Freshwater. Internet J. Microbiol., Available from: http://www.ispub.com/ostia/index.php?xmlFilePath=journals/ijmb/vol2n 2/algae.xml

15. Kilic, A.; Baysallar, M.; Besirbellioglu, B.; Salih, B.; Sarkun, K.; Tanyuksel, M. (2005). In vitro antimicrobial activity of propolis against methicillin-resistant Staphylococcus aureus and vancomycin-resistant Enterococcus facium. Ann. Microbiol. 55 (2), 113-117.

16. Kosalec, I.; Bakmaz, M.; Pepeljnjak, S. (2003). Analysis of propolis from the continental and Adriatic regions of Croatia. Acta. Pharm., 53 (4), 275-285.

17. Krol, W.; Scheller, S.; Shenai, J.; Pietsz, G.; Czuba, Z. (1993). Synergistic effect of ethanol extract of propolis and antibiotics on the growth of Staphylococcus aureus. Arzneim. Forsch. Drug Res. 43 (5), 607-609.

18. Kujumgiev, A.; Bankova, V.; Ignatova, S. (1993). Antibacterial activity of propolis, some of its components and their analogs. Pharmazie. 48 (10), 785-786.

19. Lu, L.C.; Chen, Y.W.; Chou, C.C. (2005). Antibacterial activity of propolis against Staphylococcus aureus. Int. J. Food Microbiol. 102, $213-220$.

20. Menzes, H.; Bacci, M.; Oliveira, S.D.; Pagnocca, F.C. (1997). Antibacterial properties of propolis and products containing propolis from Brazil. Apidologie. 28 (2), 71-76.

21. Metzner, J.; Schneidewind, E.M.; Friedrich, E. (1977). On the effects of propolis and pinocembrin on blastomyces. Pharmazie. 32 (11), 730.

22. Mohammadzadeh, S.; Shariatpanahi, M.; Hamedi, M.; Ahmadkhaniha, R.; Samadi, N.; Ostad, S.N. (2007). Chemical composition, oral toxicity and antimicrobial activity of Iranian propolis. J. Food Chem. 103, 1097-
1103.

23. Muli, E.M.; Maingi, J.M. (2007). Antibacterial activity of Apis mellifera L. Propolis collected in three regions of Kenya. J. Venom. Anim. Toxins incl. Trop. Dis. 13 (3), 655-663.

24. Orsi, R.D.O.; Sforcin, J.M.; Funari, S.R.C.; Junior, A.F.; Bankova, V. (2006). Synergistic effect of propolis and antibiotics on the Salmonella typhi. Braz. J. Microbiol. 37, 108-112.

25. Petersen, A.; Andersen, J.S.; Kaewmak, T.; Somsiri, T.; Dalsgaard, A. (2002). Impact of Integrated Fish Farming on Antimicrobial Resistance in a Pond Environment. Appl. Environ. Microbiol. 68 (12), 6036-6042.

26. Qaiyami, S. (2007). Macro- and Microdilution methods of antimicrobial Suscebtibility Testing. In: Schwalbe, R., Steele-Moore, L., Goodwin, A.C. (Eds.), Antimicrobial Suscebtibility Testing Protocols. Taylor \& francis Group, New York, USA, p.75-81.

27. Saroglou, V.; Karioti, A.; Demetzos, C.; Dimas, K.; Skaltsa, H. (2005). Sesquiterpene Lactones from Centaurea spinosa and Their Antibacterial and Cytotoxic Activities. J. Nat. Prod. 68, 1404-1407.

28. Sawaya, A.C.H.F.; Souza, K.S.S.; Maria C. Marcucci, M.C.; Cunha, I.B.S.; Shimizu, M.T. (2004). Analysis of the composition of Brazilian Propolis extracts chromatography and evaluation of their In vitro activity against Gram- positive bacteria. Braz. J. Microbiol. 35, 104-109.

29. Scheller, S.; Szaflarski, J.; Tustanowski, J.; Nolewajka, E.; Stojko, A. (1977). Biological properties and clinical application of propolis. I. Some physicochemical properties of propolis. Arzneim. Forsch. Drug Res, 27 (4), 889-890.

30. Soares, M.M.S.R.; Cury, A.E. (2001). In vitro activity of antifungal and antiseptic agent dermatophyte isolations from patients with Tinea pedis. Braz. J. Microbiol. 32, 130-134.

31. Takaisi-Kikuni, N.B.; Schilcher, H. (1994). Electron Microscopic and Microcalorimetric Investigations of the Possible Mechanism of the Antibacterial Action of a Defined Propolis Provenance. Planta. Med. 60 (3), 222-227.

32. Tegos, G.; Stermitz, F.R.; Lomovskaya, O.; Lewis, K. (2002). Multidrug Pump Inhibitors Uncover Remarkable Activity of Plant Antimicrobials. Antimicrob. Agents. Chemother. 46 (10), 3133-3143.

33. Yang, H.Y.; Ho, W.L.; Chang, C.M.; Chou, C.C. (2007). Antibacterial Activity of Propolis Ethanol Extract against Streptococcus mutans as Influenced by Concentration, Temperature, $\mathrm{pH}$ and Cell Age [Online]. JFD. 15 (1), 75-81. 